\title{
The implications of neoliberalism for the care of orphans in Zimbabwe: Challenges and opportunities for social work practice
}

\author{
Munyaradzi Muchacha ${ }^{1}$, Charles Dziro ${ }^{2}$ and Edmos Mtetwa²
}

${ }^{1}$ Graduate student, University of Lincoln, UK

2 School of Social Work, University of Zimbabwe
AOTEAROA

NEW ZEALAND SOCIAL WORK 28(2), 84-93.

CORRESPONDENCE TO: Munyaradzi Muchacha munyaradzimuchacha@ gmail.com

\begin{abstract}
The paper explores the implications of neoliberal social policies for the care of orphans in Zimbabwe and looks at the challenges and opportunities for social work practice in such a context. It is estimated that Zimbabwe is home to over 1 million orphaned and vulnerable children most of whom are being looked after by their relatives. As from 1991, Zimbabwe switched over from a "socialist" socio-economic policy trajectory to a neoliberal dispensation. This neoliberal policy regime entails the implementation of austerity measures such as severe cuts on social expenditures, the introduction of stringent means tested social safety nets and reduction of the civil service wage bill. This paper argues that this neoliberal policy regime negatively affects the care of orphans and access to services such as health and education. The reduction of expenditure on social services has also resulted in severe cuts on social work posts within the civil service leading to high caseloads and poor social work practice. The paper concludes by identifying and arguing for developmental social work practice as a social work strategy to challenge and address the implications of neoliberalism through strengthening the capacities of the kinship system, advocacy and contribution to the social policy making process.
\end{abstract}

KEYWORDS: neoliberalism; social policy; orphans; social work; Zimbabwe

\section{Introduction}

Zimbabwe is a landlocked country located in Southern Africa with an estimated population of 13 million people. It lies in the semi-arid region characterised by unreliable rainfall and extreme temperatures, hence it is susceptible to drought (Chagutah, 2010). Since independence from British rule in 1980, Zimbabwe has been under the leadership of Robert Mugabe of the Zimbabwe African National Union - Patriotic Front (ZANUPF) party. Between the years 1980-1990, Zimbabwe enjoyed a decade of economic prosperity and massive extension of social services to the black majority population who were marginalised by the colonial apartheid (Kanyenze, 2006). However, this economic prosperity was short lived. From 1991, the country experienced protracted and deep seated socio-economic and political challenges (Coltart, 2008). At the centre of these challenges were economic demise, high prevalence of extreme poverty, unemployment and HIV and AIDS (Gandure, 2009). Many scholars (see for example, Chan 2003; Kanyenze, 2006; Coltart 2008) attribute these structural socio-economic and political challenges to bad governance and retrogressive social and economic policies implemented by the ZANU-PF led government.

Neoliberal ideas such as economic liberalisation, austerity and privatisation have increasingly influenced the character and direction of social and economic policies in Zimbabwe (Kanyenze et al., 2011). The height of this economic liberalisation and austerity in Zimbabwe was from 1990-1996 when the country adopted the Structural Adjustments Programmes (SAPs). During SAPs, social 
funding towards social services such as health and education was drastically reduced and user fees were introduced. Since the SAPs era, most social policies in Zimbabwe such as cash transfers, health and education social safety nets are underlined by neoliberal values and elements such as stringent means testing and limited coverage.

This paper argues that neoliberal social policies are negatively impacting on the care of orphaned children in Zimbabwe. This country has an estimated over 1 million orphaned children largely as a result of HIV and AIDS (Government of Zimbabwe, 2010). Most of these children are being taken care of largely by their kin. However due to the increase in orphans, the challenging socioeconomic situation and limited support from the state, the kinship system is under severe strain (Mushunje, 2006). Furthermore, the nature and quality of social work practice in Zimbabwe has been significantly impacted by neoliberal policies. For example, social workers are operating with limited essential resources such as vehicles, office space and stationery which are critical for social workers to perform their functions (Wyatt, Mupedziswa \& Rayment, 2010). Further to that, the government has frozen social work vacancies as part of efforts to curb the wage bill resulting in inadequate social workers and huge caseloads (Wyatt et al., 2010). The paper concludes by identifying and arguing for developmental social work practice as a potentially innovative social work approach to support vulnerable families in this neoliberal context.

\section{Background and context}

Zimbabwe inherited an economy which was performing fairly well from the British in 1980. This economy had high Gross Domestic Product (GDP), manufacturing outputs, exports and low unemployment (International Labour Organisation (ILO), 1993). However, the weakness associated with this economy is that it was primarily in the hands of the white minority (Mlambo, 1997). From 1980 to 1990, the Robert Mugabe led government managed to maintain and steer remarkable economic growth and stability (Richardson, 2004). Kanyenze et al. (2011) provides various indicators which shows this economic growth and stability. They note:

- “GDP grew at phenomenal rates of 11 per cent and 10 per cent in 1980 and 1981, respectively.

- Gross investment in capital stock as a percentage of GDP rose from 14.8 per cent in 1980 to 15.5 per cent in 1981.

- Capacity utilization followed the same trend, rising from 83 per cent in 1980 to 95 per cent in 1983.

- The economy grew at close to the target rate of 5.1 per cent, averaging 4.6 per cent per annum for the period 1986-90.

- Employment grew at an average annual rate of 2.7 per cent from 1986-90".

(Kanyenze et al., 2011, p.35)

Equally important, this period witnessed massive government investments and expansion of social services such as education, health, housing and water and sanitation (Dhliwayo, 2001; Gandure, 2009). This was instrumental in addressing the past racial imbalances and apartheid policies created by the Rhodesian (Zimbabwe colonial name) government.

The economic stability, growth and universal access to social services that characterised the years from 1980 -1990 did not go beyond 1990 (Mlambo, 1997). As earlier highlighted, in 1991 on the recommendation of the International Monetary Fund and the World Bank, Zimbabwe joined many other countries across the world in implementing SAPs (Central Statistical Office, 1998; ILO, 1993; Dhliwayo, 2001). SAPs were meant to free the fiscal space and reduce government interventions in the economy and labour market as well as increased foreign direct investments and investor confidence (Richardson, 2004).

On the contrary, in many countries SAPs did not lead to economic development as 
envisaged. Instead, they had dire social, economic and even political effects. In the case of Zimbabwe, these neoliberal measures culminated in economic stagnation, recession and increased poverty and vulnerability. For example, the prevalence of extreme poverty increased from an estimated 40.4\% in 1990 to about $63.3 \%$ in 1995 (Central Statistical Office, 1998). SAPs had similar negative consequences in other countries such as Ghana, Jamaica, Trinidad and Tobago, Uganda, Nigeria and Malawi (Easterly 2003; Asad, 2004; Munthali, 2004; Heidhues and Obare, 2011). In Ghana, the introduction of user fees on education led to an increase of primary school dropout by $40 \%$. The privatisation of water supply services led to an increase in prices and limited access by disadvantaged members of society (Asad, 2004). In Cote d'Ivoire, from 1989-1993, per capita GDP fell by $15 \%$, between 1988-1995, the population living below $\$ 1$ per day increased from $17.6 \%$ to $36 \%$ (Asad, 2004).

The year 2008 is regarded as the height of the economic instability when inflation was over $150000 \%$ (Coltart, 2008). This same year had many socio-economic developments, such as a disputed election which was marred by politically motivated violence, a huge increase in the cost of living, shortages of basic commodities and a cholera outbreak that killed over 10000 people. In 2009, to avert the humanitarian crisis, Zimbabwe established a government of national unity mainly between the Movement for Democratic Change (the main opposition party) and ZANU (PF). The government of national unity marked a period of economic stability and witnessed remarkable improvements in the delivery of services such as water, health and education. In 2013, ZANU (PF) won another disputed election. Its government which is currently in power is however struggling to maintain the economic stability acquired during the government of national unity. For example, the country is currently experiencing a huge liquidity crunch which has led to a shortage of cash in banks. Furthermore, unemployment and corruption is endemic.
The social work profession in Zimbabwe plays a role in addressing social problems (Chogugudza, 2009). Non-Governmental Organisations (NGOs) mostly employ social workers as development workers, and their social workers play developmental and non-traditional roles such as economic strengthening, promoting food security and livelihoods, enabling access to water and sanitation and dealing with the challenges of orphaned and vulnerable children (Chogugudza, 2009). For instance, in 2008 during the cholera epidemic, NGO social workers were involved in activities such as advocacy for equitable access to clean and safe water, community sensitisations on water and sanitation, enabling access to health and provision of water and sanitation facilities. Another group of social workers are those who are employed by the government Department of Social Welfare, which is the single largest employer of social workers in Zimbabwe (Dziro, 2013). Social work practice in the government was a wholesale importation from the colonial period and has received criticism for being curative, remedial and failing to address the major social problems peculiar to the local context (Mhiribidi, 2010). For example, the major social problems in Zimbabwe include chronic poverty, high unemployment, corruption and limited access to social services such as water, education and health. These structural challenges cannot be addressed by casework, the major social work method utilised in the Department of Social Welfare (Mhiribidi, 2010). Social workers in this department play traditional roles such as means testing, casework and probation work (Chogugudza, 2009).

\section{The situation of orphans in Zimbabwe}

The HIV and AIDS pandemic has created a phenomenal increase in orphan-hood and the vulnerability of children in Zimbabwe. Approximately over 1 million children are orphaned as a result of HIV and AIDS in Zimbabwe (Government of Zimbabwe, 2010). The Zimbabwe Vulnerability 
Assessment Committee (ZIMVAC), a nationwide socio-economic barometer in Zimbabwe, indicated that two-thirds of orphans live below the poverty datum line (Zimbabwe Vulnerability Assessment Committee (ZIMVAC), 2014). Mushunje (2006) observed that orphaned children are often exposed to neglect, abuse and exploitation. Similarly, Dhlembeu \& Mayanga (2006) contend that orphans are more likely to experience abuse, sexual exploitation and psychosocial distress than children who are not orphaned (Government of Zimbabwe, 2010).

Powell et al. (2004) estimates that over 94 percent of orphans in Zimbabwe are in kinship care. The National Orphan Care Policy (the policy framework for the care and support of orphans in Zimbabwe) is explicit that the best place for all children including orphans is within a family (Government of Zimbabwe, 1999). This policy also emphasises that alternative care models such as formal foster care, residential care and adoption should be utilised as a last resort. It places emphasis on strengthening of the kinship family system so that it can be in a position to meet the various socioeconomic needs of children (Government of Zimbabwe, 1999; Mushunje, 2006). Without the kinship system in Zimbabwe most orphans could probably have been destitute or in more difficult circumstances than they are in currently. Kinship orphan care is part of the African traditional system and philosophy dubbed Ubuntu in local dialect (Mugumbate \& Nyanguru, 2013). Ubuntu is a philosophy and cultural practice which entails communal and collective care of vulnerable members of kin. Ubuntu played a significant role during the colonial era in meeting the various needs of indigenous people, as most of the social services by the colonial regime only supported the whites.

As earlier mentioned, the kinship based orphan care system is under constant threat due to an increased number of orphans due to the epidemic and the economic crisis currently facing the country (Foster, 2000).
Matshalaga (2004) highlights other factors that are weakening the extended family which includes migration and demographic changes. The pursuit of a neoliberal economic policy trajectory has further constrained the capacity of families to look after their orphaned children due to reduced funding of social services such as health care, education, and social assistance (Mushunje, 2006). This has simply left the burden of care on the extended family including older persons (Gandure, 2009). For example, Matshalaga (2004) observed that older persons taking care of orphans were struggling to provide the needs of children such as food, clothing and education.

\section{The impact of neoliberal social policies on the care of orphaned children}

Almost all social safety nets for orphans in Zimbabwe have a narrow reach and involve stringent means testing, to the extent that some children who are orphaned and living in vulnerable families do not qualify. This section discusses the qualifying criteria and reach of three major social safety nets for orphans in Zimbabwe, in particular how their stringent means testing and limited coverage negatively impact the care of orphans. The selected social safety nets are the Assisted Medical Treatment Orders (AMTO) (health social safety net), Basic Education Assistant Module (BEAM) (school fees social safety net) and cash transfers which targets orphans in ultra-poor and labour constrained households (Muchacha, 2015). These government social safety nets were introduced in recent years after the economic structural adjustment programme. Due to limited fiscal space, these social safety nets are mostly funded by multilateral donors.

The Basic Education Assistance Module (BEAM) was introduced in the year 2000. The main objective of the programme is to enable access to education for orphans and vulnerable children through payment of school fees. Every school has a committee 
known as the BEAM community selection committee. This committee consists of various stakeholders such as teachers and community leaders. The role of the committee is to select children considered to be extremely vulnerable and regarded as the most deserving in the whole community. After selection by this committee, the social workers working in the Department of Social Welfare conduct further verification. In 2008, during the hyperinflation era, this social safety net was almost dysfunctional as the funds were eroded by inflation. The programme however resumed during the government of national unity and is in place to date.

This social safety net has two major gaps. Firstly, unlike the universal education policies in place soon after independence, BEAM involves stringent means testing which excludes other vulnerable children who may not be viewed by the selection committee as the most deserving. Secondly, the funding for BEAM is too limited to meet the demand. For example, in 2010 a total of 573,245 children benefitted from this social safety net (Muchacha, 2015). This is almost half of the total orphans and vulnerable children. There is however no empirical research which explains the fate of children who were not assisted by BEAM. Possible explanations are that some had their fees paid by the extended family and NGOs, while some could not access education. ZIMVAC (2014) estimates that over $48 \%$ of children in Zimbabwe are not accessing education. The proportion of households of children not going to school was found higher in households with orphans than those without (ZIMVAC, 2014). A study by Muchacha (2015) revealed that most orphans and vulnerable children had challenges in accessing education owing to lack of money (ZIMVAC, 2014).

Other than the payment of the tuition fees and levies, the caregivers are expected to meet additional educational costs. These costs include examination fees, stationery and school uniforms. All these educational provisions are mandatory for every child
(Muchacha, 2015). Because of such additional educational expenses, orphans and other vulnerable children usually fail to transition from primary to secondary education given that fees for secondary education are higher. In conclusion, Muchacha (2015) observes that primary school attendance among orphans tends to be higher in primary school and drastically drops at secondary and tertiary levels. As alluded to earlier, this is evidence that the neoliberal policy trajectory taken by the government of Zimbabwe coupled with the prevailing political and economic challenges bedevilling the country adversely affects the underprivileged and vulnerable members of the society.

Another safety net that has become critical in the care of orphans in Zimbabwe is the social cash transfer programme. This programme is funded and implemented by both government and donor agencies that include the Department for International Development among others. Social cash transfer programmes are not peculiar to Zimbabwe. In southern Africa, such countries as South Africa, Zambia, Malawi and Lesotho also support vulnerable households with social cash transfers (Schubert, 2010). In fact, social cash transfers have gained popularity across the globe to economically empower vulnerable households. The social cash transfer programme in Zimbabwe largely targets households taking care of orphaned children, with each household receiving US $\$ 20$ per month. This social safety net also employs stringent qualifying criteria that raises the risk of leaving out other households in dire need of assistance. The qualifying criteria is household living below the food poverty datum line and which is ultra-poor and labour constrained (Schubert, 2010). The government of Zimbabwe regards as labour constrained those households that have such characteristics as:

- "Households with no able bodied member in the 18 to 59 age group, who is fit for productive work.

- Household members that cannot work or should not work because they are under 
18 years of age or over 59 or are unfit for work because they are chronically ill, or disabled or handicapped or are still schooling" (Schubert, 2010, p.16).

A close analysis of this qualifying criteria shows that the government assumes that persons who are fit to work are positioned to have access to employment and provide for the vulnerable children. This neoliberal assumption is flawed considering that unemployment in Zimbabwe currently stands at over $80 \%$ (Gandure, 2009). This qualifying criteria excludes all orphans who are in households in which the caregivers are categorised as fit to work. Equally important, from the year 2011 - 2015 the cash transfer programme has been targeting a total of 250,000 households (Government of Zimbabwe, 2010). 250,000 is a very limited target considering that there are over one million orphans in Zimbabwe (Schubert, 2010). In addition, an estimated $63 \%$ of households in Zimbabwe are living in poverty. Of these, $16 \%$ are estimated to be in extreme poverty (ZIMVAC, 2014). More than half of orphans live in households which are affected by poverty (Government of Zimbabwe, 2010). These statistics indicate that a huge number of orphans in Zimbabwe are living in poverty and the cash transfer programme is currently far from meeting the current demand.

The last social safety net under scrutiny is the Assisted Medical Treatment Order (AMTO). It seeks to enhance access to health for vulnerable persons such as those in extreme poverty, older persons, orphans and persons with disabilities. Its qualifying criteria are persons in any of those groups who cannot afford to pay for their medical expenses. The means testing is done by social workers who make a referral to government medical institutions. This social safety has been experiencing severe challenges, the major one being that the government is failing to pay for the debt it owes the medical institutions. For example, Langa (2014) observed that the government owes medical institutions about US\$3 million.
The permanent secretary in the Ministry of Public Service, Labour and Social Welfare is cited by Langa (2014) highlighting that "vulnerable households in need of health assistance through the Assisted Medical Treatment Order (AMTO) may fail to access health services due to the cumulative effect of non-payment of hospital bills since 2013." From 2011 to 2015, the government targeted to reach a total 25000 children through this social safety net (Government of Zimbabwe, 2010). There are no available statistics which show the extent to which orphaned children are accessing AMTO, however it is apparent that this target is too marginal to meet the health needs of the orphans in Zimbabwe.

\section{Challenges for social work practice}

Social work practice is greatly affected by its social, economic and political context. The government of Zimbabwe austerity measure to cut the wage bill has severely reduced the social service workforce (Wyatt et al., 2010). This has not only left many social workers out of employment, but has further compromised social service delivery particularly the care and protection of orphaned children provided by social workers. An Institutional Capacity Assessment of the Department of Social Welfare showed that the department had immense capacity challenges due mainly to staff shortages (Wyatt et al., 2010). For instance, this assessment indicated that there are over 1 million orphaned and vulnerable children in need of social work services (Government of Zimbabwe, 2010). Compared to its southern African neighbours, Zimbabwe has the largest child to social worker ratio. Wyatt et al. (2010) observed that the ratio of children to social workers in Zimbabwe currently stands at $49,587: 1$. This is compared with $1,867: 1$ in Botswana and 4,300:1 in Namibia. Due to the limited social work opportunities and difficult work conditions, many social workers have migrated to countries such as South Africa, Namibia, Australia and United Kingdom to secure better opportunities (Chogugudza, 2009). 
The government has been drastically reducing its funding for administrative purposes to Ministries (Wyatt et al., 2010). The Institutional Capacity Assessment of the Department of Social Welfare showed that this department has an acute shortage of administrative resources such as office space, stationery, fuel and vehicles. This assessment noted that in many instances social workers borrow vehicles from the local NGOs to execute functions such as home visits, probation work, family tracing and placement of children in alternative care. These statutory functions are mostly executed by social workers in the Department of Social Welfare and in situations where resources are not available these activities are delayed or put on hold. Wyatt et al. (2010) concluded that this department "is extremely under-resourced to meet the challenges it faces, in terms of the number of vacancies among professional front-line staff, the professional qualifications and experience of many of the staff who are in post, and the physical facilities and resources at their disposal" (p.7). This is a major drawback to the progress that was made soon after independence, when Zimbabwe had one of the best social welfare systems in the region (Wyatt et al., 2010).

The socio-economic situation in Zimbabwe has witnessed a phenomenal increase in the number of NGOs which are dealing with the crisis and filling the vacuum left by the government. Most of these NGOs employ social workers and they provide various services such as child protection, psychosocial support, economic strengthening and education. The contribution by the NGOs in addressing the situation of orphaned children in Zimbabwe has been both positive and negative. The positive aspect is that some NGOs have managed to enable provision of services identified which the government is struggling to meet such as fees and health care assistance. Conversely, some intervention strategies employed by some NGOs have been considered detrimental to the care of orphans and vulnerable children.
For instance, a number of NGOs particularly faith-based charities have constructed residential facilities to institutionalise children defying government's policy of promoting family and community as opposed to institutional child care (Powell et al., 2004). Even though these efforts are well intentioned, residential care has proved to be very costly and unsustainable given the socio-economic situation of the country (Powell et al., 2004). Expansion of residential care facilities runs parallel to the National Orphan Care Policy that emphasises family and community care and which stipulates that resources should be channelled towards the care of orphans within a family or communal environment (Powell et al., 2004).

Another concern levelled against the operations of NGOs is that most of their activities are not coordinated or harmonised with government programmes. This has led to such challenges as duplication of efforts and piecemeal provision of services that fail to holistically address the economic, social, educational and other needs of children (Jimmat, 2010).

\section{Opportunities for social work practice}

Neoliberal social policies are now deep seated and central to the political and economic discourse in Zimbabwe. To be realistic, neoliberal policies are not going to be scrapped in the near future. In light of this policy thrust, social workers in Zimbabwe need to explore innovative strategies to support vulnerable families to sustainably care for orphans and vulnerable children in the absence of reliable formal social safety nets (Mhiribidi, 2010). It is evident that case work and other related approaches that are currently dominating social work practice in Zimbabwe are not positioned to address the structural challenges such as chronic poverty, high unemployment, and limited access to social services, social and economic crisis and austerity. To that end, this paper adds a voice to other African scholars calling for a paradigm shift towards 
developmental social work practice (Patel, 2005; Gray, 2010). Developmental social work has been hailed by these scholars as a "home grown" approach customised largely to deal with socio-economic challenges peculiar to the Global South. It is here argued that developmental social work practice has several strengths and opportunities in addressing the implications of neoliberal policies in Zimbabwe. The developmental approach is credited for its appropriateness in the pursuit of equity, social justice and propoor socio-economic policies (Patel, 2005).

Developmental social work is defined by Gray and Simpson (1998) as:

a multifaceted approach aimed at empowering and building the capacity of people and organizations to meet social needs and to develop social resources; which comprises non-remedial forms of intervention; which is concerned with non-material resources, such as people's participation, community support and naturally occurring networks; and is concerned with material gains, linking social work with economic development in that real empowerment comes from the achievement of economic independence and autonomy. (p.229)

Undergirded by the values of social justice and human rights, developmental social work is a strength based approach that seeks to promote self-reliance, equitable access to resource systems and economic inclusion. Developmental social work activities include advocacy, economic and social empowerment, social policy formulation and community participation, collaborations and networking (Gray, 2010)

As earlier pointed out, the kinship care system remains central to the care of orphans and vulnerable children. This is a crucial support system that social workers in Zimbabwe need to support and strengthen further. Developmental social work provides a potentially unique opportunity for the strengthening of this system. This is so given that developmental social work is a strength based approach and it acknowledges and argues for the support and strengthening of prevailing strengths (Gray, 2010). In this regards, social workers need to identify the survival and coping strategies employed by various families and communities and explore mechanisms to leverage them. Social workers possess various developmental social work skills such as networking, resource mobilisation, capacity building, research, problem solving and monitoring and evaluation. Gray (2010) concurs "social workers have the knowledge, skills and value framework needed to take on this challenge, the major stumbling block being whether or not social workers consider development a valid form of practice and context of social work activity"(p.8). These developmental social work skills are essential in strengthening the capacities of vulnerable families. Muchacha (2015) contends that families are increasingly undertaking various income generating initiatives such as gardening, farming, carpentry and animal husbandry to cope with unemployment. Social workers can therefore play various non-traditional and developmental roles to support these income generating initiatives or empower families to initiate new ones. For instance, social workers may link caregivers to microfinance facilities, markets, arrange specialised trainings, and capacity build communities in the area of business management.

It is imperative to highlight that some NGOs have been innovative in the development and implementation of services which are developmental in nature to support orphaned and vulnerable children which can provide lessons for the government. The example that quickly comes to mind is that of Oasis Zimbabwe. This is a community based NGO in Zimbabwe that supports caregivers who are taking care of orphaned children with capacity building services such as training and funding to start and run income generating projects such as poultry, baking, gardening and tailoring. The proceeds from such income 
generating projects are channelled towards the educational requirements of orphans and other vulnerable children. Under such an arrangement, social workers are responsible for training of the caregivers on book keeping, financial management and marketing. They also link the caregivers to potential markets. The major strength of this programme is that it incorporates and mainstreams critical elements such as promotion of self-reliance, sustainability and community participation and ownership.

Developmental social work argues for equitable access to resources and economic opportunities, and it identifies neoliberal policies as a key driver to structural inequalities. It therefore, challenges social workers to advocate for inclusive social and economic policies (Gray, 2010). In this regard, social workers in Zimbabwe need to engage in strong advocacy against austerity measures. Social workers need to amplify their voice against austerity through their various platforms such as civil society organisations and professional bodies such as the National Association of Social WorkerZimbabwe. Social workers also need to empower and capacity build communities to create grassroots social movements capable of engaging in advocacy activities such as petitioning the local politicians. Equally important, developmental social work calls upon social workers to actively contribute to the formulation of socio-economic policies. This paper bemoans the fact that there is limited involvement of social workers in the development of socio-economic policies in Zimbabwe. As such, the paper argues for the increased participation of social workers in contributing towards inclusive and pro-poor social policies. It is also pertinent that social workers create platforms and opportunities for vulnerable populations to contribute to social policy making process.

\section{Conclusion}

This paper argued that neoliberal policies in Zimbabwe have adversely impacted the care of orphans. The paper demonstrates that most of the orphaned children remain in the care of their extended families, however the increasing number of orphaned children, high unemployment, poverty and limited support from the state serve to compromise the resilience of the extended family to continue providing for such children. The paper further argues that developmental social work offers many opportunities to address the implications of neoliberal policies through innovative social work practices meant to strengthen the capacity of vulnerable families to take care of orphans. The strength of a developmental approach is that it positions social workers to advocate against structural inequality, social injustice and perennial poverty borne out of a skewed social and economic platform anchored upon a neoliberal policy trajectory.

\section{References}

Asad, I. (2006). Impoverishing a continent: The World Bank and the IMF in Africa. Retrieved from http://www.halifaxinitiative.org/updir/ ImpoverishingAContinent.pdf.

Brett, E.A. (2005). From corporatism to liberalization in Zimbabwe: Economic policy regimes and political crisis, 1980-97. International Political Science Review, 26(1), 91-106.

Central Statistical Office. (1998). Poverty in Zimbabwe. Harare: Central Statistical Office.

Chan, S. (2003). Robert Mugabe: a life of power and violence. London: Tauris.

Coltart, D. (2008). A decade of suffering in Zimbabwe, economic collapse and political repression under Robert Mugabe, Development Policy Analysis, No. 5. Retrieved from http://www.cato.org/publications/developmentpolicy-analysis/decade-suffering-zimbabwe-economiccollapse-political-repression-under-robert-mugabe

Chagutah T. (2010). Climate change vulnerability and preparedness in Southern Africa: Zimbabwe country report. Cape Town: Heinrich Boell Stiftung.

Chogugudza, C. (2009). Social work education, training in Africa: the case of Zimbabwe. Ufuhamu: A Journal of African Studies, 35(1), 1-9.

Dhlembeu, N., \& Mayanga, N. (2006). Responding to orphans and other vulnerable children's crisis: Development of Zimbabwe's national plan of action. Journal of Social Development in Africa, 21(1), 35-49.

Dhliwayo, R. (2001). The Impact of public expenditure management under EASP on basic social services: health and education. Paper presented at the Structural Adjustment Participatory Review Initiative (SAPRI) Poverty Reduction Forum, Harare, Zimbabwe.

Dziro, C. (2013). Trends in social work education and training: The case of Zimbabwe. International Journal of Development and Sustainability, 2(2), 423-1435. 
Gray, M. (2002). Developmental social work: a strengths praxis for social development. Social Development Issues, 24(1), 4-14.

Gray, M. \& Simpson, B. (1998). Developmental social work education: A South African Example. International Journal of Social Work, 41(2), 227-237.

Easterly, W. (2003). IMF and World Bank Structural Adjustment Programs and Poverty. Massachusetts: National Bureau of Economic Research.

Foster, G. (2000). The capacity of the extended family safety net for orphans in Africa. Psychology Health and Medicine, 5(1), 56-62.

Gandure, S. (2009). Baseline Study of Social Protection in Zimbabwe, A Report for the Social Protection Technical Review Group (SPTRG) of the Multi-Donor Trust Fund. Harare: UNICEF.

Government of Zimbabwe .(2010). National Action Plan for Orphans and VulnerableChildren Concept Note. Harare: Ministry of Labour and Social Services.

Government of Zimbabwe. (1999). National Orphan Care Policy. Harare: Government Printers.

Heidhues, F., \& Obare, G. (2011). Lessons from Structural Adjustment Programmes and their Effects in Africa. Quarterly Journal of International Agriculture, 50(1), 55-64.

Jimmat. (2010). Programme of support for the National Action Plan for Orphans and Vulnerable Children outcome assessment, final report. Harare:Jimmat.

Kanyenze, G., Kondo, T., Chitambara, P., \& Martens, J. (2011). Beyond the Enclave: Towards a Pro-Poor and Inclusive Development Strategy for Zimbabwe. Harare: Weaver Press.

Kanyenze, G. (2006). Economic policies making processes, implementation and impact in Zimbabwe. Harare: Centre for rural development.

Langa, V. (2014, December 27). Poor fail to access health services. Newsday. Retrieved from https://www.newsday.co.zw

Mhiribidi, S.T.W. (2010). Promoting the Developmental Social Welfare approach in Zimbabwe: Challenges and Prospects. Journal of Social Development in Africa, 25(2), 121-146.

Munthali, T. (2004). The impact of Structural Adjustment Policies (SAPS) on manufacturing growth in Malawi. Unpublished PhD dissertation. University of Leeds, United Kingdom.

Muchacha, M. (2015). An evaluation of the implementation of the National Case Management Model in Zimbabwe. (Unpublished Masters dissertation). University of Kwazulu Natal, South Africa.

Mugumbate, J., \& Nyanguru, A. (2013). Exploring African philosophy: the value of Ubuntu in social work. African Journal of Social Work, 3(1), 82-100.

Mushunje, M. T. (2006). Child protection in Zimbabwe: Yesterday, today and tomorrow. Journal of Social Development in Africa, 21(1), 12-34.

Patel, L. (2005). Social Welfare and Social Development in South Africa. Cape Town: Oxford University Southern Africa.

Powell, G., Chinake, T., Mudzinge, D., Maambira, W., \& Mukutiri, S. (2004). Children in residential care: The Zimbabwean experience. Harare: Ministry of Public Service, Labour and Social Welfare/UNICEF.
Richardson, C. (2004). The Collapse of Zimbabwe in the wake of the 2000-2003 land reforms. Lampeter: The Edwin Mellen Press.

Mlambo, A. S. (1997). The economic Structural Adjustment Programme: The case of Zimbabwe, 1990-1995. Harare: University of Zimbabwe Publications.

Matshalaga, N. (2004). Grandmothers and orphan care in Zimbabwe. Harare: SAFAIDS.

Schubert, B. (2010). Design of the Zimbabwe harmonized social cash transfer programme. Harare: Ministry of Labour and Social Service and UNICEF.

UNICEF. (2010). Child protection fund, strategic concept \& design. Harare: UNICEF.

Wyatt, A., Mupedziswa, R., \& Rayment, C. (2010). Institutional capacity assessment. Harare: UNICEF and Ministry of Labour and Social Services.

Zimbabwe Vulnerability Assessment Committee (ZimVac). (2014). Rural Vulnerability Assessment. Harare: Zimbabwe Vulnerability Assessment Committee. 